\title{
Restriction Enzyme Analysis
}

National Cancer Institute

\section{Source}

National Cancer Institute. Restriction Enzyme Analysis. NCI Thesaurus. Code C19581.

Identification of restriction enzyme sites in DNA samples or DNA sequences. 